\title{
公営住宅におけるグループホーム等の使用に関する研究 A STUDY ON USE FOR GROUP HOME IN PUBLIC HOUSING
}

\author{
山田信博*, 藤田 忍**, 辻 壽一*** \\ YAMADA Nobuhiro, FUJITA Shinobu and TSUJI Toshikazu
}

\begin{abstract}
Installation of the group home is called for as supply of a residence to elderly people or a disabled person. In recent years, it is advanced except the shift and institution to an area. Under the influence, the organization which uses public housing as a group home has appeared. Then, Article 45 of Public Housing Law is added at the time of the Public Housing Law revision in 1996, and a social welfare corporation etc. can use public housing now at a group home care home etc. Although it is thought that the use number of houses will increase from now on, the number of use, the trend and validity, a problem, etc. in the whole country are not clarified. In this research, it aims at acquiring the knowledge about the state of future use by investigation for use examples, such as a group home which uses public housing.
\end{abstract}

Keywords : Public housing, group home, care home, stock use, conversion

公営住宅，グループホーム，ケアホーム，ストック活用，コンバージョン

\section{1. 研究の背景と目的}

急速な高齢化とともに、公営住宅においても高齢化が進行し、単 身高齢者や高齢者夫婦世帯が非常に多くなってきた。その為に、高 齢者の孤独死や自治会活動の低下によるコミュニティの崩壊などが 起きている。それらの問題に対して、地方公共団体は国土交通省が 策定した「高齢者住宅整備計画」による、シルバーハウジング型や コレクティブ八ウジング型公営住宅の建設を行っている。その他に も、同じく国土交通省の「公営住宅団地建替えにおける社会福祉施 設の併設に関する指針」により、1 階部分に福祉施設等が併設され た公営住宅の建設が行われている。

しかし現在の社会状況の中では、新たな建設ではなく既存建築の ストック活用が求められている。海外（主にヨーロッパ）では大規 模な増改築や減築、コンバージョンによる既存建築を活かした団地 再生活動が行われているが、日本では幾つかの法律による規制と、 柱や梁を取り除く事が出来ず、大きな床面積の確保が困難などの建 築構造による規制により、公営住宅における住居用途以外一の転用 は非常に少ない。多くは「公営住宅ストック総合改善事業」により、 補修や小規模増築、間取りの変更や設備の更新などを行い、住居と して使用しているのが現状である。

既存の施設を使用した事例では、集会所を利用した「ふれあい喫 茶」などの活動を行っている団地があり、効果を得ているようだ。 しかし、それらの多くは期間の限定された一時的使用であり、効果 を上げるためには長期的な活動の場が必要である。

認知症高齢者や知的障害者・精神障害者への住宅の供給として、 グループホーム (以下 $\mathrm{G} \mathrm{H}$ ) ・ケアホーム (以下 $\mathrm{C} \mathrm{H}$ ) の設置が求め られている。近年、地域一の移行と脱施設化を進めており、重要な
施策として位置付けられているが、運営を行っている社会福祉法人 の経済的状況から場の確保が難しくなっている。それらの問題から、 一部の社会福祉法人が活動の場を公営住宅に求め、平成 4 年 4 月北 海道上磯町営住宅、平成 5 年 4 月静岡県営住宅（袋井市）、平成 6 年 4 月徳島県営住宅（板野郡）において、管理主体が補助金適正化 法に基づく目的外使用の承認を得て、公営住宅の住戸を $\mathrm{GH}$ として 試験的に使用し始めた。その影響もあり、平成 8 年の公営住宅法改 正時に第 45 条が追加され、社会福祉法人等注1)が公営住宅を GH・ $\mathrm{CH}$ 等注2)で使用出来る事が正式に認められた。その後の法改正で、 使用者（N P O等）や使用事業（ホームレス自立支援事業）が追加 されている。

本研究では、公営住宅法第 45 条における GH・CH等の使用事 例を対象とし、全国の使用実績、使用内容、使用に関する管理主体 の動向を調查する。そして、管理主体による評価と実例の考察によ り、公営住宅 $\mathrm{GH} \cdot \mathrm{CH}$ 使用の有効性や問題点を明らかにし、今後 の使用の在り方についての知見を得る事を目的とする。

本研究に関する既往研究は、日野 ${ }^{1)}$ らによる公営住宅GH使用の 2 事例を対象とした利用者の実態と交流、周辺住民とのコミュニテ イに関する考察のみであり、全国の実態把握などは行われていない。

\section{2. 研究の方法}

全国の都道府県と、義務的建築主事を置く特定行政庁および県庁 所在地の地方公共団体の計 135 管理主体（都道府県 47、市 88） 一電 話によるヒアリング調査を行った後に、「公営住宅におけるグループ ホーム等の使用および目的外使用の実態に関寸る調査」と題した調 査票を送付し、109 管理主体（都道府県 38、市 71）の回答を得た。
* 大阪市立大学大学院生活科学研究科 後期博士課程 · 学修

** 大阪市立大学大学院生活科学研究科 教授・学博

*** 大阪樟荃女子大学学芸学部インテリアデザイン学科 教授. 学博
Graduate Student, Graduate School of Human Life Science, Osaka City Univ., M. Ph. Prof., Graduate School of Human Life Science, Osaka City Univ., Ph. D.

Prof., Dept. of Interior \& Environmental Design, Osaka Shoin Women’s Univ., Ph. D. 
回収率は 80.74\%であった。その他に使用事例の考察として、大規 模な改装を行い、大阪府のモデルケースとして位置付けられている 1 団地に対してヒアリング調査と現地調查を行った。

\section{3. 全国の公営住宅 $G H \cdot C H$ 使用状況}

\section{3-1 使用戸数}

平成 20 年 11 月時点での $\mathrm{GH}$ ・CH等の使用は、109管理主体の うち 32 件である。過去に使用していたが、現在は終了している団 体が 1 件あり、過去に一度も使用した事例がない団体が 75 件で、 (未 回答 1 件）約 3 割の管理主体が $\mathrm{GH}$ ・ C H 等で使用中であるという 事が分かった（図 1 )。図 2 で示すように、使用している管理主体の 種類に、大きな差は見られない。

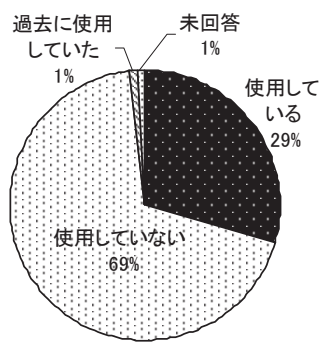

図1 $\mathrm{GH} \cdot \mathrm{CH}$ 等の使用(管理主体)

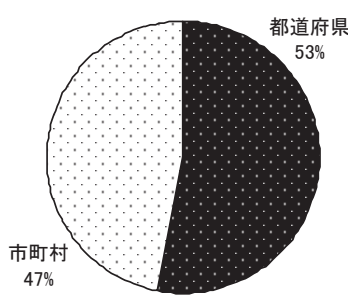

図2 使用中の管理主体
図 3 では、 $\mathrm{GH} ・ \mathrm{CH}$ 等で使用している管理主体名と使用戸数と使 用用途を示している。管理戸数の多い東京都で多く使用している他 には、長野県・愛知県・大阪市・神戸市・長崎県での使用が多く見 られた。総使用戸数は 547 戸で、その中でも一番多くの使用が大阪 府で 362 戸使用しており、全体の $66 \%$ を占めている。他の管理主 体と比べてこの大阪府の使用戸数は桁違いに多い。この理由につい ては後で述べる。2 4 戸使用中の管理主体が最も多くみられたが、 これは社会福祉法人からの要望により、試験的に $\mathrm{GH} ・ \mathrm{CH}$ 等とし て使用中だということが管理主体へのヒアリングで分かった（1ユ ニット $2 \sim 4$ 戸で構成し、 $\mathrm{GH} \cdot \mathrm{CH}$ の人数を確保)。ホームレス自 立支援事業の使用は、和歌山県の 2 戸のみである。

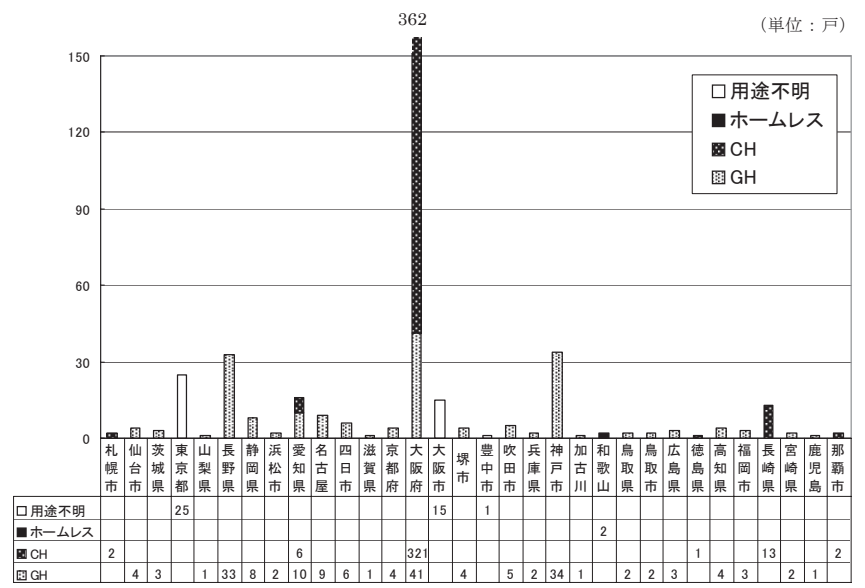

図3 $\mathrm{GH} \cdot \mathrm{CH}$ 使用状況

\section{3-2 使用団体と用途}

使用中の団体は、社会福祉法人が $83 \%$ と最も多く、医療法人と $\mathrm{N}$ P O 法人が続いて多い。地方公共団体が 2 戸の使用、不明が 1 戸で ある。厚生労働省による平成 19 年の $\mathrm{G} \mathrm{H}$ 経営主体の割合では、社 会福祉法人が $65 \%$ 、N P O法人が $17 \%$ 、医療法人が $14 \%$ であ り、公営住宅を GH等として使用中の団体は、社会福祉法人が特に 多いという傾向がみられた。(図 $4 \cdot 5$ )

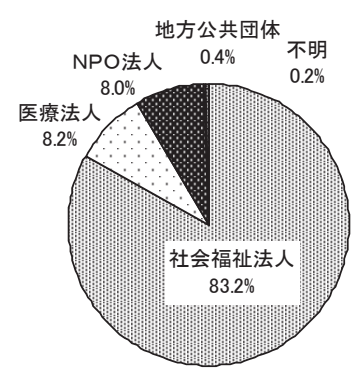

図4 使用団体

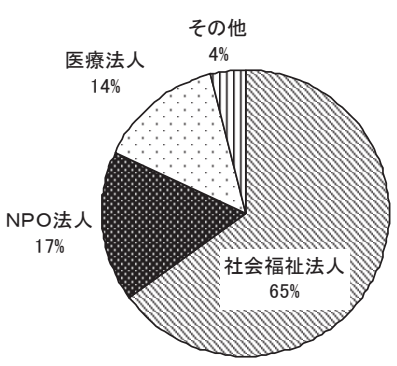

図5 GH運営団休
使用中の用途は、CHが $63 \%$ と最も多いが、使用戸数の大部分 を占める大阪府を除く管理主体では、GHが 7 \%の使用となり、 全国でみると GHの使用が多い事が読み取れる。(図 $6 \cdot 7$ )

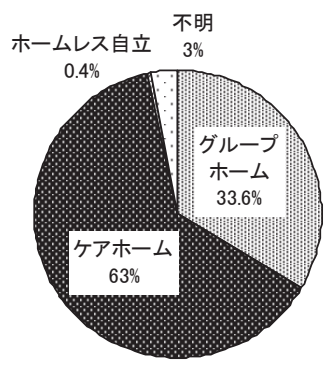

図6 使用用途(全国)

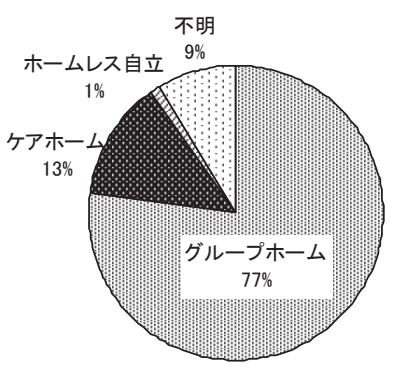

図7 使用用途 (大阪府除く)

\section{$3-3$ 使用開始年}

平成 8 年の法改正前の使用戸数が 3 戸あり、法改正 2 年後の平成 10 年から使用が増え、平成 19 年に 80 戸を越える多くの使用戸数 がある。しかし、GH 戸数は一定で、同年より GH 事業の許可が都 道府県から市町村に移管された事による影響はみられない。（図 8 )

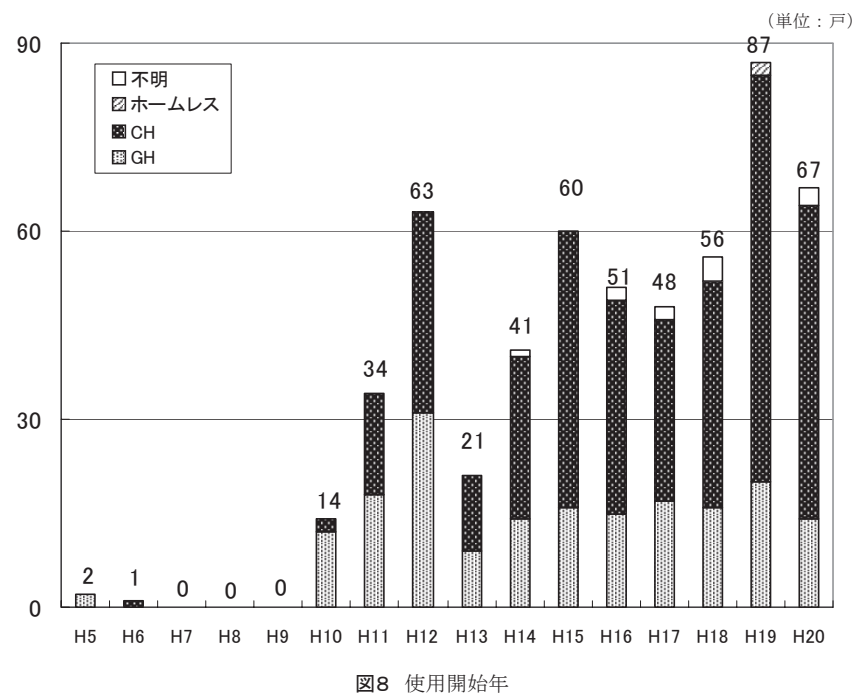




\section{3-4 住戸の種類と用途の関係}

1 住戸の使用者注 4 数は 2 人が最も多く、続いて 3 人であった。住 戸の種類は 3 D K が最も多く、2 D K が続いて多い事が分かる。こ の事により、多くの GH・CHでは、3 D Kもしくは $2 \mathrm{DK}$ K 2 戸 使用して 1 ユニットを運用し、個室の確保が可能な 4 人〜 6 人で使 用（世話人が 1 名）していると推測される。

住戸の種類と使用用途との関係は、住戸面積が小さい場合は G H、 大きい場合は C Hでの使用が多いという特徴が見られた。これは介 護が必要な $\mathrm{C} \mathrm{H}$ と、必要の無い $\mathrm{GH}$ 年れぞれの特徵からだと考えら れる (図 9 )。他にも、同一ユニットにおける住戸の位置は、大阪府 を除く GHでは $74 \%$ が同一階で構成されているが、大阪府では 5 $5 \%$ 。大阪府を除くCHでは $100 \%$ 同一階で構成されていたが、 大阪府では $55 \%$ であった。大阪府では、 G H・CH共に約半分の ユニットで階数の違う住戸を使用している事が大きな特徵であり、 特にCHでは階数が違っても運営が可能なようである。

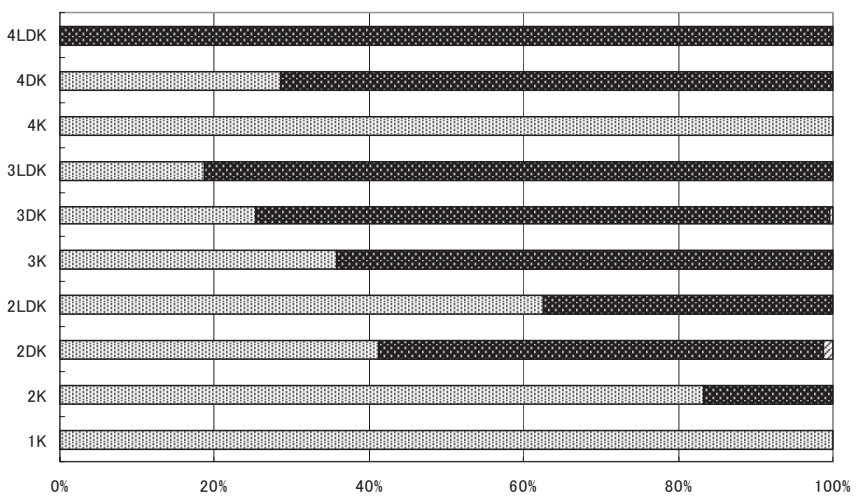

图グループホーム 図9間取りと用途の割合

图ケアホーム

曰ホームレス自立支援

\section{3-5 住戸内部の改装と階数}

管理主体や使用団体注3) による住居内部の改装は、行わずにその ままの状態で使用している住戸が多い。その理由として、使用終了 時に現状復帰義務があり、大規模な改装は費用的に困難ということ がある。2 戸の住戸を 1 住戸に改装するという大規模な G H ・ C H は、数件であった。他にも、介護等の必要がない使用者の為、改装 の必要はないという意見もあった。軽微な改装を行っている事例で は、火災に対する不安から、ガスコンロから I Hへの変更、報知機 の設置、手寸りの設置を行っている。トイレや浴室の交換といった 中規模な改装を行っている住戸が $11 \%$ であった。（図 10)

使用住戸の階数は 1 階が最も多く、その他の階では差があまり見 られない。1 階の使用が最も多い理由としては、管理主体の配慮と 団体からの要望によることが、ヒアリングにより分かった。(図 11)

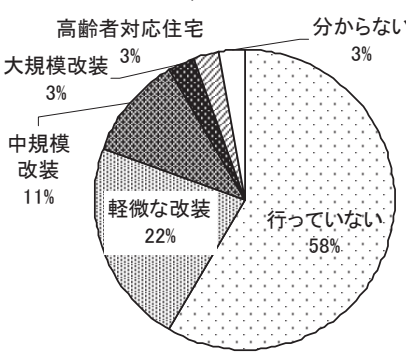

図10 改装の有無

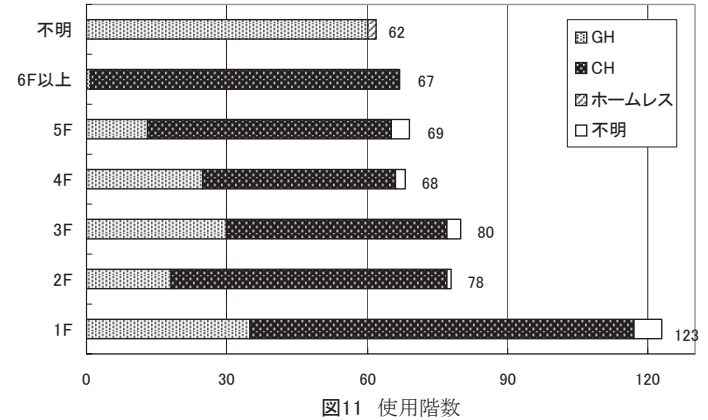

4. 管理主体の意識

\section{4-1 使用の可否}

「現在管理する公営住宅を GH・CHとして使用できるか」の問 いに対して、59\%が「使用できる」と答え、 $23 \%$ 「使用できない」 と答えた。使用できない主な理由は、入居希望者が多く「使用でき る住戸が確保できない」が $84 \%$ となり、住戸の狭さやエレベータ 一・浴室などがない、段差がありバリアフリー対応していない等の 理由で、「GH等として使用できる住戸が無い」が $12 \%$ ああった。 今までに使用希望者がおらず、管理主体内で検討をしていないので 「分からない」が $18 \%$ であった。中にはGH・CHとして使用する には、大規模な施設や設備が必要なので、公営住宅での使用は非現 実的だと答える管理主体の担当者がおり、現在多くの一般家屋や民 間マンションで $\mathrm{GH}$ ・ CHが運営されているという事が知られてお らず、担当者の知識不足を感じた。（図 $12 \cdot 13)$

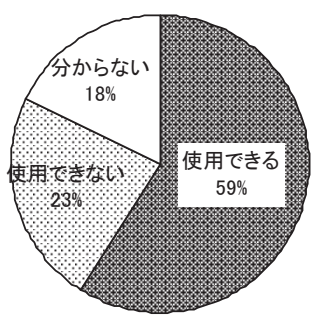

図12 グループホーム使用の可否

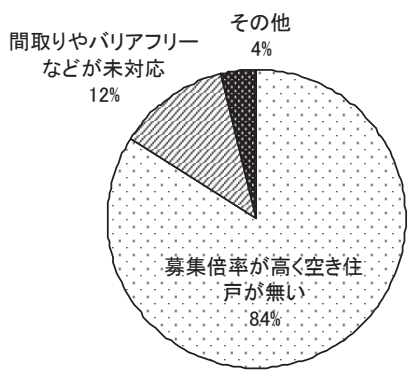

図13 使用できない主な理由

\section{4-2 設置基準と法人等への告知}

一般的な G H運営基準以外に、公営住宅 G H使用における独自の 運営基準については、43\%が「特にない」、34\%が「使用団体に基 準がある」、3\%が「使用者に基準がある」、20\%が「使用団体、使 用者共に基準がある」という結果になった。使用団体への主な基準 は、使用団体側で自治会等への説明を行い事前に了解を得る事や、 世話人の基準、G H事業の円滑な実施の担保、自治会費の支払いを 確約、税金の滞納が無い事が挙げられた。(図 14)

管理主体側から社会福祉法人等へ、公営住宅を GH等で使用でき ることを告知しているかについて、82\%の管理主体が「行っていな い」 $14 \%$ が「行っている」という結果になった。告知をしない主 な理由は「使用できる住戸の確保が出来ない」が最も多く、本来の 使用目的を阻害する恐れがあるので「積極的に告知すべきでない」 が 10\%であった。他にも、条例に定めている、使用までの経緯が未 
整備の為、法律で決まっている事を改めて告知する必要はない、な どの意見もあった。（図 15）

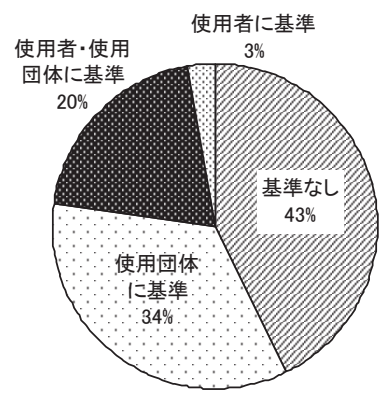

図14 管理主体独自の基準

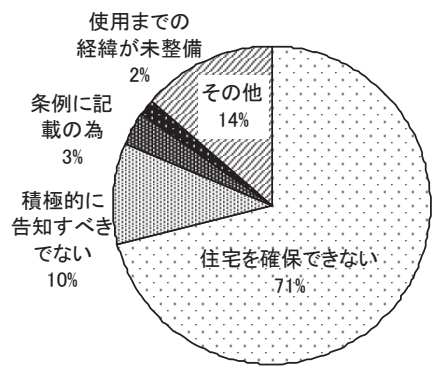

図15 告知しない主な理由
告知をしている場合の方法で、最も多かったのが $45 \%$ の「決まっ ていない」その次に公営住宅関連空口ではなく「福祉関係課より告 知をしている」が $31 \%$ あた。福祉関係課の方が社会福祉法人等と 接する機会が多い為だと考えられる。

告知をしている管理主体の使用率は $46 \%$ 、告知をしていない管理 主体の使用率は $27 \%$ で、告知をしている方が $19 \%$ も使用率が高い という結果になった。これは依然として、公営住宅を $\mathrm{GH}$ ・ C H 等 で使用できるという事が、社会福祉法人等に知られていないという 事と、G H・CHの使用は管理主体側の姿勢に大きく影響している 事が考えられる。

\section{5. 使用までの経緯と団地居住者の反応}

$41 \%$ の管理主体が使用希望の相談を受けた事があり、そのうち $36 \%$ が使用に至っている。使用出来なかった場合の主な理由は、空 き住戸の確保ができなかった、法人団体ではなかった、要望する住 宅の確保ができなかった、住民の反対、というものであった。

使用の要望をどこへ申し出ればいいのか分からない、という社会 福祉法人担当者の意見もあるようで、管理主体内での空口や審査等 の経過を明確に決めておく必要があると考えられる。多くの場合、 福祉関係課に相談があり、公営住宅管理課と協議寸るという流れの ようである。

居住者注5)からの要求や反応は、使用前では約 6 割が「何もなし」、 説明の要求が $19 \%$ 、使用についての要求が $9 \%$ 、使用反対の要求 は $9 \%$ であった。使用後は約 9 割が「何もなし」、使用反対意見は $3 \%$ であった。この結果から、多くの居住者は $\mathrm{G} \mathrm{H} ・ \mathrm{CH}$ 使用に対する 要求が無く、反対意見も少ない。これは居住者の関心の低さが考え られるが、他にも、使用後の反対意見の低さから、使用者がトラブ ル等を起こさず居住者と共存している事が分かる。(図 $16 \cdot 17$ )

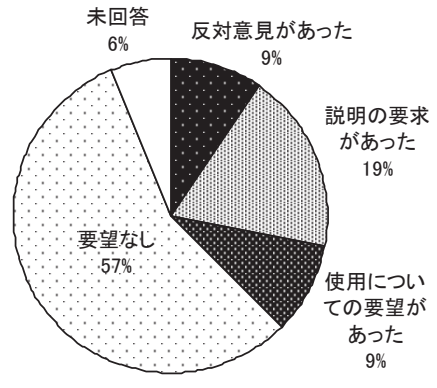

図16 居住者からの要望(使用前)

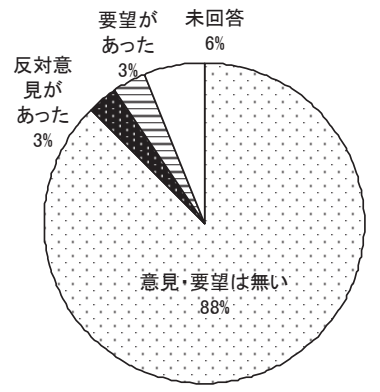

図17 居住等からの要望(使用後)
管理主体もしくは使用団体から居住者への使用に関する説明は $78 \%$ で行っており、多くの場合入居前に行っている。説明後は、 $92 \%$ が合意を得て使用に至っており、事前に使用の説明を行い居住者の 不安を取り除く事で、円滑な使用が可能である事が分かった。（図 1 $8 \cdot 19)$
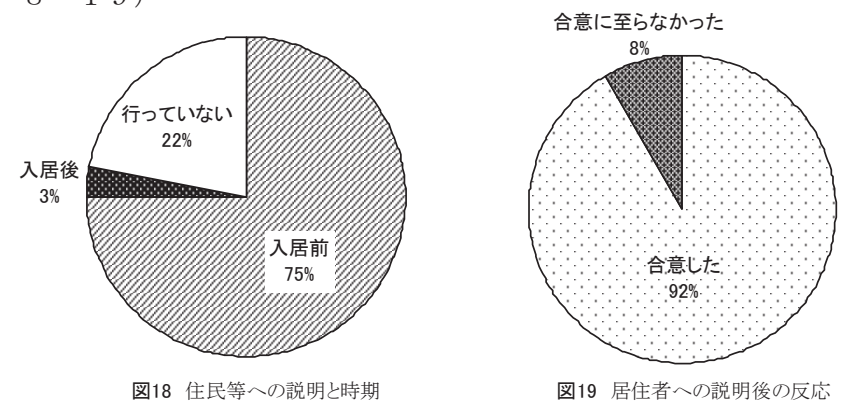

図19 居住者への説明後の反応

\section{6. 使用終了の理由と今後の方針}

使用が終了した場合の理由は、80\%が使用者側からの希望で終了 している。その理由として、試験的に使用してみたが、住戸が狭く て住み難い。使用者が働く仕事場の近くに住宅の確保が出来なかっ た為、通勤時間が長くなってしまった。使用団体の拠点から遠い、 等があった。期間が定められていたという管理主体側の理由が $20 \%$ あった。現在 GH・CH等として使用中の管理主体による今後の使 用方針は、条件付も含め約 9 割の管理主体が今後も続けていく意向 である。(図 $20 \cdot 21$ )
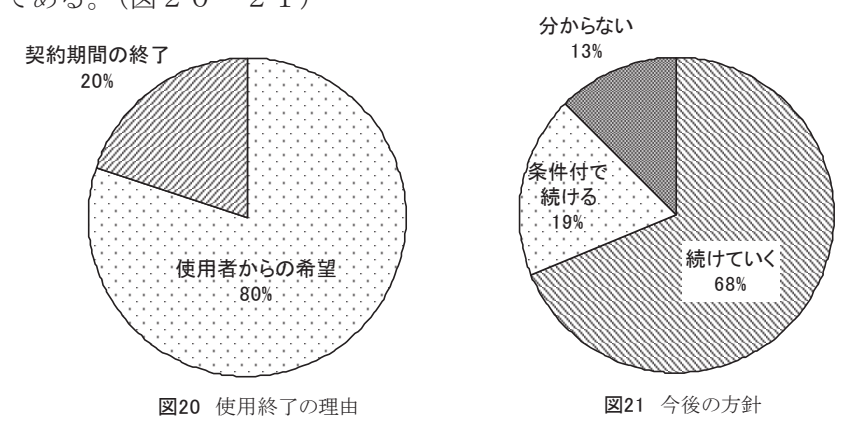

\section{7. 大阪府における $\mathrm{GH} \cdot \mathrm{CH}$ 等の使用}

\section{7-1 大阪府の取り組み}

$3-1$ で示したように、大阪府における $\mathrm{GH}$ ・ C H 等の使用が圧 倒的に多い。これは平成 8 年より、「大阪府まちづくりマスタープラ ン」において、知的障害者・精神障害者や、認知症高齢者が住夕慣 れた地域で生活する場を確保するため、公営住宅 G H・C H の活用 が推進されているからである。これにより大阪府は、障害者や認知 症高齢者への住宅の供給に力を入れている事が分かる。

使用の推進が行われている事もあり、希望から使用までの流れや 手順が大阪府内で明確に決められている。福祉部で希望をまとめ、 住宅まちづくり部で提供住戸の選定を行い、福祉部で審査を行うと いう手順になっている。他にも、 $\mathrm{GH} \cdot \mathrm{CH}$ 等の使用についての告 知を行っていない管理主体が多いにも関わらず、大阪府から府内の 社会福祉法人一、年に 2 度「使用意向調查」を実施している事が特 徵である。平成 9 年より開始しており、平成 20 年度は 176 法人に 実施している。これにより、大阪府内の社会福祉法人には、公営住 宅を使用できることが周知されている。 


\section{7-2 大規模改装型の事例}

大阪府営 $\mathrm{A}$ 住宅は昭和 49 年の建設で、 2 L D K の住戸が 20 戸、 5 階建の住棟である。1 階の 2 住戸を 1 住戸とし、外部テラスを新 設した大規模改装型の公営住宅GHである。大阪府はこの G H を府 営住宅活用モデル事業に位置付けている。(図 22 ・写真 $1 \sim 6$ )

「概要」

・平成 15 年 7 月より使用開始

• 床面積 $105 \mathrm{~m}^{2}$

- 高齢者認知症 $\mathrm{GH}$

・使用者 6 名（全て女性）

「入居条件

・要支援 2 要介護 5 に該当する

・共同生活が可能で、ある程度身の回りのことができる

・常時医療機関において治療を必要としない

施設型 G H とは違い非常に家庭的な雾囲気が、この公営住宅 GH の大きな特徴である。内部は、大きな外部テラスに面したサンルー ムが印象的で、使用者は、食堂・デイルームで団らんの時間を過ご していた。屝も全て引き戸に交換しており、廊下幅も車い寸対応で あった。トイレや浴室も新たに交換されており、1階だが半階分の 階段使用が必要な事以外は、不自由さは感じられなかった。見学者 のほとんどが、入居を希望するそうである。世話人が自治会活動に も積極的に参加しており、居住者との交流も心がけているようだ。

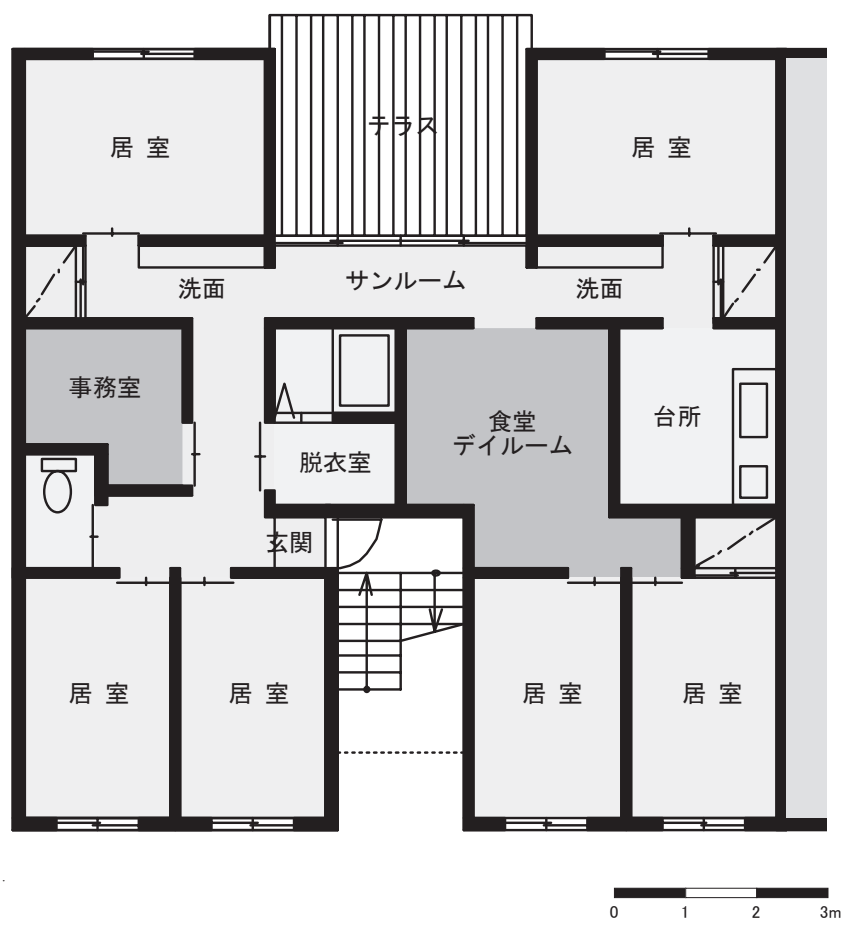

図22 平面図
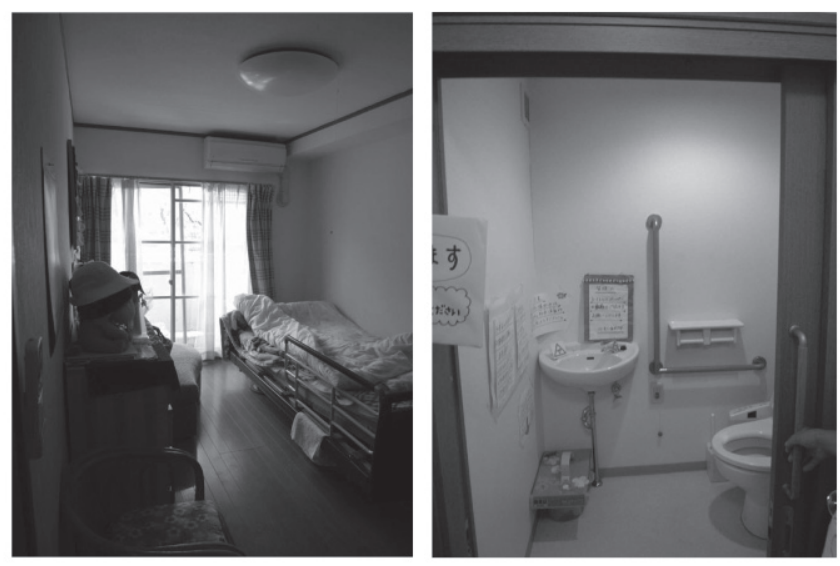

写真1 居室

写真2 トイレ
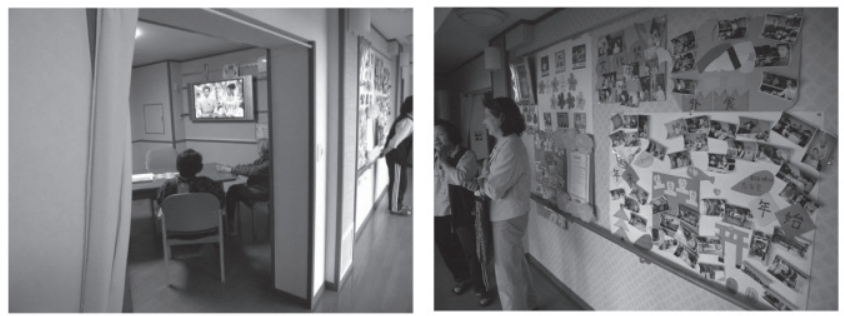

写真3 デイルーム

写真4 サンルーム

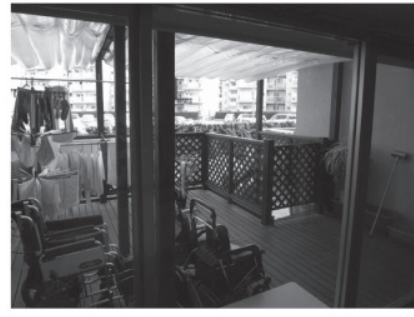

写真5 テラス

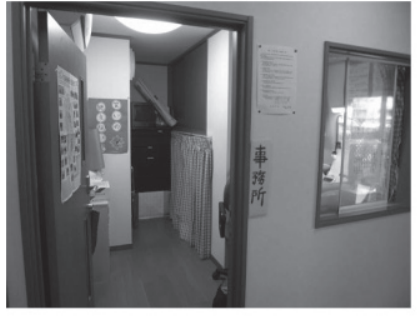

写真6 事務所
8 まとめ

1 ) 約 3 割の管理主体が公営住宅を $\mathrm{GH} ・ \mathrm{CH}$ として使用中で、全 戸数は 572 戸であった。大阪府で多くの使用戸数が見られた が、多くの管理主体は平成 8 年の法改正後、社会福祉法人から の要望により、試験的に $1 \sim 2$ ユニット（ 2 ユ 4 戸）を使用し ているようである。未使用の管理主体では、公営住宅法では使 用可能だが、依然として一般の住居入居希望者が多く、住戸の 確保が困難であり、本来の目的である住居の供給が主な業務だ と捉えている。

2 ）使用者と居住者によるトラブルは少ないが、扉の開け閉め、足 音などの騒音に関する苦情があるようである。多くは概ね良好 な関係を築いているようである。居住者と会った時は必ず挨拶 を行う」というルールを設けている $\mathrm{CH}$ もあった。入居前に居 住者からの反対で、使用を断念した事例も数例あったが、入居 前に管理主体や使用団体から居住者へ説明を行う事で、合意に 至る場合が多いようである。

3 ) 使用中の管理主体の多くは、1階の住戸を提供している。認知 症高齢者はエレベーターの無い上階での生活は厳しいが、知的 
障害者・精神障害者においては、必ずしも 1 階である必要はな いように推測されるが、下階への騷音が心配なので、最下階を 要望するという傾向がある。住戸内部の改装も、知的障害者・ 精神障害者においては、火災予防などの軽微な改装で使用出来 る事が分かった。

4) 住宅の規模は、1ユニット：2～ 3 D K × 2 住戸による構成が 多いようである。しかし、使用者数と個室数が同じ場合、世話 人がダイニングやキッチン等で就寝するといった問題も起こっ ている。2 住戸で構成される事で、男性住戸・女性住戸と区分 出来るという運営上の利点もあり、3 住戸以上になると、隣接 した住宅の確保が難しくなるという傾向がみられた。一方、隣 接していない離れた住戸で構成されたユニットは、住戸間の移 動が不便、食事の運搬が不便といった問題がある。しかし、移 動の必然性により、居住者と挨拶などの接する機会が生まれる などといった良い面も見出されている。

5 ) 今後、管理主体の GH・CH使用に対する積極的な姿勢に期待 したい。多くの管理主体担当者は、 $\mathrm{GH}$ - C Hの使用は、「本来 の目的である住宅の供給を阻害する恐れがある」と述べた。し かし、知的障害者・精神障害者や認知症高齢者も住宅困窮者で ある、公営住宅法で使用が認められている以上、一般に住宅を 求める人と同じく提供の機会を与える必要があると考える。そ して、今以上に公営住宅を $\mathrm{GH}$ ・ C H 等で使用できることを、 社会福祉法人一周知寸る必要があると考える。

都市部における G H・CH等の運営団体は、活動場所の確保 に大変苦労しており、民間賃貸住宅で運営する場合、家賃の高 さが利用者への大きな負担となっている。公営住宅を使用する 事で、家賃の安さ・場の確保の他に、「施設以外で暮らすことで、 社会復帰の訓練が期待される」という良さも見られた。

\section{謝辞}

本研究にあたり、お忙しい中ご協力頂きました全国の管理主体関係 者の皆様、公営住宅居住者の皆様、社会福祉法人の皆様方に深く感 謝申し上げます

\section{注}

注 1 ) 公営住宅法 45 条第 1 項における「社会福祉法人等」とは、公営住宅 法第四十五条第一項の事業等を定める省令第 2 条における下記の者で ある。

(1)地方公共団体

(2)医療法人

(3)一般社団法人又は一般財団法人

(4)特定非営利活動促進法に基づき設立された特定非営利活動法人

(5)小規模住居型児童養育事業を行う者、若しくは児童自立生活援助事業 を行う者で都道府県等から委託を受けているもの

(6)介護保険法に規定する指定地域密着型サービス事業者で、認知症対応 型共同生活介護を行うもの、又は同法に規定する指定地域密着型介護 予防サービス事業者で、介護予防認知症対応型共同生活介護を行うも の

注 2 ）公営住宅法第 45 条第 1 項における「社会福祉法人等が使用できる事 業」とは、公営住宅法第四十五条第一項の事業等を定める省令第 1 条 における下記の 4 事業である。

(1)览童福祉法に規定する児童自立生活援助事業
(2)老人福祉法に規定する認知症対応型老人共同生活援助事業 (3)障害者自立支援法に規定する共同生活介護又は共同生活援助を行う事 業

(4)ホームレスの自立の支援等に関する特別措置法規定するホームレス自 立支援事業により就業した者に対して生活上の支援を行う事業

注 3 ) 公営住宅を $\mathrm{GH} \cdot \mathrm{CH}$ 等で運用中の社会福祉法人等

注 4 ) 公営住宅 $\mathrm{GH} \cdot \mathrm{CH}$ 等の利用者

注 5 ) $\mathrm{GH} \cdot \mathrm{CH}$ 等で使用中の公営住宅の居住者

\section{参考文献}

1）日野孝彦・田上健一: 公営住宅団地におけるグループホーム設置による 新たな居住コミュニティ、日本建築学会九州支部計画系研究報告 第 47 号, pp57-60, 2008.3

2) 日本住宅協会：公営住宅管理必携 平成 18 年度版 2006.12

3 ) 住本靖著：新公営住宅法逐条解説 商事法務研究会 1997.7

4）住本靖著：知っておきたい公営住宅法 大蔵省印刷局 1997.1

5 ) 公営住宅制度研究会編 : 地域住宅特別措置法・改正公営住宅法等の解説 ぎょうせい 2006.6

6 ）大阪府：大阪府営住宅ストック総合活用計画 2007.1

7 ）日本建築学会編：集合住宅のリノベーション 技報堂出版 2004.3 